\title{
Herpesviridae reactivation for poor outcome in ARDS patients with ECMO: criminal or witness?
}

\author{
Huixue Huang ${ }^{1}$ and Hangyong $\mathrm{He}^{2^{*}}$ (1)
}

Dear editor,

We read with interest of the report by Hraiech and colleagues [1] about the Herpesviridae reactivation among non-immunocompromised critically ill patients with acute respiratory distress syndrome (ARDS) supported with extracorporeal membrane oxygenation (ECMO). They found that Herpesviridae reactivation is frequent among patients with severe ARDS under ECMO and is associated with a longer duration of mechanical ventilation. From our point of view, a few other concerns related to who, how and why for the Herpesviridae reactivation affects outcome in ARDS could be raised.

First, who has a Herpesviridae reactivation should be focused? In Hraiech's study [1], they determined the frequency of Herpesviridae reactivation and its impact on prognosis only in patients during ECMO for severe ARDS. However, Herpesviridae reactivation occurring in all ARDS patients should be investigated. Within all ARDS patients, by comparing the reactivation related to ARDS with no-ECMO support, and the reactivation after ECMO insertion, whether a Herpesviridae reactivation was worsening under ECMO could be confirmed.

The second question is how a Herpesviridae reactivation or active infection should be defined in ARDS patients? In Hraiech's report [1], Herpes Simplex Virus

\footnotetext{
*Correspondence: yonghang2004@sina.com

${ }^{2}$ Department of Respiratory and Critical Care Medicine, Beijing

Institute of Respiratory Medicine, Beijing Chao-Yang Hospital, Capital Medical University, No. 8 Gongren Tiyuchang Nanlu, Chaoyang District, Beijing 100020, China

Full list of author information is available at the end of the article

A comment to this article is available at https://doi.org/10.1186/s1361
} 3-019-0616-6
(HSV) reactivation was diagnosed mainly by throat or BAL samples, and only 3 patients (5\%) exhibited a positive HSV viremia, and cytomegalovirus (CMV) reactivation was diagnosed mainly from blood PCR. However, whether a positive PCR from the airway sample should be treated as a reactivation or as an evidence of infection is still debatable [2]. Previous study [3, 4] found that seropositivity for Epstein-Barr virus (EBV), one of Herpesviridae, was associated with mortality of ICU patients with respiratory failure. Thus, when looking for the association of reactivation and the outcome, we suggested that only patients with a seropositivity for Herpesviridae should be included. Furthermore, Hraiech and colleagues [1] found that HSV reactivation occurred earlier than CMV reactivation. In our study, airway sample may show an earlier and higher positivity than serum samples for EBV [3]. Therefore, the time of reactivation for HSV and CMV should be compared for samples from serum and airway, respectively.

Finally, why Herpesviridae reactivation caused a poor outcome in ARDS patients with ECMO support is still unclear. On the one hand, Herpesviridae reactivation may indicate an active infection and related damage to the organ function, which lead to a poor prognosis. However, in Hraiech's study [1], the definition of reactivation by a positive airway sample could not interpreted as true infection. And they reported that alveolar procollagen III level, an indicator of pulmonary fibrosis, was not different between both groups. These results could not support that reactivation leads a poor outcome by infection. On the other hand, in our previous report [3], the seropositivity for EBV associated with mortality maybe correlated with a low $\mathrm{CD} 3+\mathrm{CD} 8+\mathrm{T}$ cell count. Thus, the 
biomarkers of an ARDS or sepsis-induced immunoparalysis should be explored as a possible mechanism of reactivation and poor outcome [5].

Overall, whether Herpesviridae reactivation is directly responsible for worse clinical outcomes or if it is a consequence and a witness of the severity of the disease, as in ARDS populations with/without ECMO, still needs further investigation.

\section{Abbreviations}

ARDS: acute respiratory distress syndrome; CMV: cytomegalovirus; EBV: Epstein-Barr virus; ECMO: extracorporeal membrane oxygenation; HSV: Herpes Simplex Virus.

\section{Acknowledgements}

None.

\section{Authors' contributions}

Both authors are responsible for study design, writing. Both authors read and approved the final manuscript.

\section{Funding}

None.

Availability of data and materials

Not applicable.

Ethics approval and consent to participate

Not applicable.

\section{Consent for publication}

Not applicable.

\section{Competing interests}

The authors declare that they have no competing interests.

\section{Author details}

${ }^{1}$ Department of Internal Medicine, Beijing University of Technology Hospital, Beijing, China. ${ }^{2}$ Department of Respiratory and Critical Care Medicine, Beijing Institute of Respiratory Medicine, Beijing Chao-Yang Hospital, Capital Medical University, No. 8 Gongren Tiyuchang Nanlu, Chaoyang District, Beijing 100020, China.

Received: 27 December 2019 Accepted: 12 January 2020

Published online: 28 January 2020

\section{References}

1. Hraiech S, Bonnardel E, Guervilly C, Fabre C, Loundou A, Forel JM, Adda M, Parzy G, Cavaille G, Coiffard B, et al. Herpes simplex virus and Cytomegalovirus reactivation among severe ARDS patients under veno-venous ECMO. Ann Intensive Care. 2019;9(1):142.

2. Luyt CE, Forel JM, Hajage D, Jaber S, Cayot-Constantin S, Rimmele T, Coupez E, Lu Q, Diallo MH, Penot-Ragon C, et al. Acyclovir for mechanically ventilated patients with herpes simplex virus oropharyngeal reactivation: a randomized clinical trial. JAMA Intern Med. 2019. https:// doi.org/10.1001/jamainternmed.2019.5713.

3. He H, Wang Y, Wu M, Sun B. Positive Epstein-Barr virus detection and mortality in respiratory failure patients admitted to the intensive care unit. Clin Respir J. 2017;11(6):895-900.

4. Libert N, Bigaillon C, Chargari C, Bensalah M, Muller V, Merat S, de Rudnicki S. Epstein-Barr virus reactivation in critically ill immunocompetent patients. Biomed J. 2015;38(1):70-6.

5. Textoris J, Mallet F. Immunosuppression and herpes viral reactivation in intensive care unit patients: one size does not fit all. Crit Care. 2017;21(1):230.

\section{Publisher's Note}

Springer Nature remains neutral with regard to jurisdictional claims in published maps and institutional affiliations.

\section{Submit your manuscript to a SpringerOpen ${ }^{\circ}$ journal and benefit from:}

- Convenient online submission

- Rigorous peer review

- Open access: articles freely available online

- High visibility within the field

- Retaining the copyright to your article

Submit your next manuscript at $\boldsymbol{\nabla}$ springeropen.com 